\title{
Focal dermal hypoplasia (Goltz syndrome)
}

\author{
Guadalupe X. Corona-Guerra ${ }^{1 *}$ and Marisol Ochoa-Apreza² \\ ${ }^{1}$ Servicio de Pediatría; ${ }^{2}$ Servicio de Dermatología Pediátrica. Hospital General de San Juan del Río, Querétaro, Mexico
}

\begin{abstract}
Background: Focal dermal hypoplasia or Goltz syndrome is a rare X-linked dominant inherited genodermatosis, affecting both the ectodermal and mesodermal tissue. Clinical manifestations include skin abnormalities, defects in eyes, teeth, nails, mouth, soft tissues, and skeleton. The diagnosis is based on clinical findings and is suspected in individuals with ectodermal abnormalities and characteristic malformations in the extremities. The management is multidisciplinary and, like the prognosis, depends on the specific alterations that each patient presents. Case report: We report the case of a 15-day-old female newborn with alopecic areas on the scalp, herniation of subcutaneous cellular tissue at the lumbar level, nasal wing notch, severe left superior limb defect with rhizomelia (proximal segment shortening), and radio aplasia, as well as right leg ectrodactyly, areas of atrophy compatible with focal dermal hypoplasia according to diagnostic criteria. Conclusions: We present a case of female newborn patient with Goltz syndrome.
\end{abstract}

Key words: Focal dermal hypoplasia. Goltz syndrome. Skin atrophy. Ectrodactyly. Ectodermal dysplasia.

\section{Hipoplasia dérmica focal (síndrome de Goltz)}

\section{Resumen}

Introducción: La hipoplasia dérmica focal o síndrome de Goltz es una rara genodermatosis de herencia dominante ligada al $X$, que afecta al tejido proveniente de las placas del ectodermo y del mesodermo. El cuadro clínico se caracteriza por alteraciones cutáneas, oftálmicas, neurológicas, dentales, ungueales, bucales, de tejidos blandos y esqueléticas. El diagnóstico se realiza por los hallazgos clínicos en un individuo con alteraciones ectodérmicas y malformaciones características en las extremidades. El manejo es multidisciplinario y, al igual que el pronóstico, depende de las alteraciones específicas que presente cada paciente. Caso clínico: Se presenta el caso de un recién nacido de sexo femenino, de 15 días de vida, con zonas de alopecia en piel cabelluda, herniación de tejido celular subcutáneo en varias áreas de todos los segmentos corporales, escotadura en ala nasal, hendidura en encía superior, defecto grave de extremidad superior izquierda con rizomelia (acortamiento de segmento proximal) y aplasia de radio, así como ectrodactilia de miembro pélvico derecho. Todos los hallazgos son compatibles con hipoplasia dérmica focal de acuerdo con los criterios diagnósticos. Conclusiones: Se presenta el caso de una paciente recién nacida con síndrome de Goltz.

Palabras clave: Hipoplasia dérmica focal. Síndrome de Goltz. Atrofia de piel. Ectrodactilia. Displasia ectodérmica.

Correspondence:

*Guadalupe Ximena Corona Guerra

E-mail: ximen9coro@ hotmail.com
Available online: 14-11-2018
Date of reception: 15-09-2017

Date of acceptance: 27-02-2018

DOI: 10.24875/BMHIME.M18000037
Bol Med Hosp Infant Mex. 2018;75:155-159

www.bmhim.com 


\section{Introduction}

Goltz syndrome (focal dermal hypoplasia) is a rare genodermatosis that includes alterations in different organs originated from the mesoderm and ectoderm due to mutations in the gene PORCN, located on the $\mathrm{X}$ chromosome, which is central for the proper development of these germ layers. Systemic malformations include dental, skeletal, neurological, ocular, cardiac, renal, and genitourinary alterations, among others ${ }^{1}$. Goltz syndrome mainly affects female, with $90 \%$ of cases reported in women as a result of a dominant inheritance pattern linked to the $\mathrm{X}$ chromosome ${ }^{2}$. Due to this type of inheritance, it is lethal in male patients; those who present it may be secondary to postzygotic mosaicism ${ }^{1}$. Dr. Goltz was the first to describe this condition in 1962; he outlined three cases in women with dermal hypoplasia, fatty tissue herniation, and mesoectodermal defects ${ }^{3,4}$.

The main characteristic of this syndrome is the thinning of the dermis, which produces linear lesions and depressed subcutaneous herniation. Associated findings include other abnormalities such as papillomas on the mucous membranes or skin, linear telangiectasias, dystrophic nails, alopecia, urticaria, and photosensitivity.

Focal dermal hypoplasia is a rare disorder, with about 300 reported cases of affected individuals worldwide; the exact prevalence is unknown $n^{1,4,5}$.

In this article, we present the case of a newborn with focal dermal hypoplasia (Goltz syndrome).

\section{Clinical case}

A female 15-day-old infant referred from a private hospital to the general hospital of San Juan del Río, in Querétaro, with the diagnosis of a dysmorphic syndrome. Negative family history denied, borne by C-section, product of the third pregnancy after an abortion (October 2011, the cause is unknown), and a previous C-section (a 4-year-old girl, clinically healthy). A 34-year-old mother, a 36-year-old father, with no consanguinity, a normoevolutive pregnancy, and adequate prenatal care. During the pregnancy, no apparent congenital alterations were reported (abdominal study by oligohydramnios secondary to premature rupture of membranes); low fetal reserve and intrauterine growth restriction data were found. At birth, the patient presented an 8/9 APGAR, a weight $2100 \mathrm{~g}$ (low for gestational age), a height of $45 \mathrm{~cm}$, a Capurro of 37 weeks, and a cephalic perimeter of $30 \mathrm{~cm}$.
The physical examination revealed multiple congenital anomalies: microcephaly, disseminated dermatosis in all body segments, alterations in the auricular papillae, nasal ala notch, a severe defect of the left upper extremity with rhizomelia (shortening of the proximal segment), and radial aplasia and syndactyly, as well as ectrodactyly of the right pelvic member.

The dermatosis was found spread in all the body segments: scalp, neck, anterior and posterior thorax, abdomen, and various all around the extremities; characterized by multiple areas of skin atrophy, some ulcerated areas and some with erythema, and telangiectasias, $0.5 \mathrm{~cm}$ subcutaneous cellular tissue herniation at the lumbar level and alopecia on the scalp; apparently asymptomatic lesions present since birth.

Within the diagnostic approach, the following studies were requested: echocardiogram, in which a small ductus arteriosus was detected and interatrial communication in foramen ovale of $4 \mathrm{~mm}$; an X-ray of the left upper extremity, with agenesis of radius in the left thoracic limb; renal ultrasound, with the left renal ectasia; computed tomography (CT) of simple skull, with mild ede$\mathrm{ma}$; CT of column, with the presence of spinal dysraphism closed at thoracic level, without spina bifida; and karyotype reported as 46XX. An incisional, translesional biopsy of affected and healthy skin was performed. The report of the affected skin confirmed epidermis with focal atrophy with the presence of two to three layers of keratinocytes and hypoplasia of the dermis, with very few collagen fibers, almost immediately continuing with the subcutaneous cellular tissue. The perilesional skin was reported without alterations.

Goltz syndrome was suspected due to clinical and paraclinical findings. According to the major and minor criteria shown in table 1, Goltz syndrome was confirmed by areas of alopecia and dermal atrophy in the scalp (Fig. 1), atrophy of the dermis in the thorax and anterior abdomen, ectrodactyly in the right pelvic limb (Fig. 2), nodular fat herniation at lumbar level (Fig. 3), rhizomelia and agenesis of radius in the left thoracic limb, and syndactyly. The atrophy of the epidermis and hypoplasia of the dermis were corroborated with pathology study (skin biopsy) (Fig. 4).

During her hospital stay, the patient presented early neonatal sepsis, so she was managed with intravenous antibiotics. No gastrointestinal or central nervous system alterations have been identified so far. The patient was discharged to her home, with multidisciplinary follow-up. 
Table 1. Clinical criteria for the diagnosis of focal dermal hypoplasia and percentage of presentation.

\begin{tabular}{|c|c|}
\hline Major criteria & Percentage \\
\hline $\begin{array}{l}\text { Ectodermal manifestations } \\
\text { Atrophy and areas of skin hypoplasia that follows the Blaschko's lines } \\
\text { Hypopigmented or hyperpigmented skin areas } \\
\text { Nodular fat herniation } \\
\text { Hypoplastic or dysplastic nails } \\
\text { Telangiectasias }\end{array}$ & $\begin{array}{l}95 \\
90-100 \\
60-70 \\
80-90 \\
80\end{array}$ \\
\hline $\begin{array}{l}\text { Extremity malformations } \\
\text { Syndactyly } \\
\text { Ectrodactyly } \\
\text { Oligodactyly } \\
\text { Congenital absence of hand, arm, forearm, elbow without distal portions, acheiria, or hemimelia } \\
\text { Shortening of long bones }\end{array}$ & $\begin{array}{l}70-90 \\
75 \\
20-40 \\
15 \\
50-80\end{array}$ \\
\hline Minor criteria & Percentage \\
\hline $\begin{array}{l}\text { Ectodermal manifestations } \\
\text { Alopecia, wiry hair } \\
\text { Verrucoid papillomas of the skin and mucous membranes (including in the mouth, nose, larynx, } \\
\text { esophagus, vaginal mucosa, and rectal mucosa) } \\
\text { Dental abnormalities including enamel defects } \\
\text { Hair shaft abnormalities on scanning electron microscopy }\end{array}$ & $\begin{array}{c}80 \\
65 \\
80 \\
80-90\end{array}$ \\
\hline $\begin{array}{l}\text { Other manifestations } \\
\text { Iris coloboma } \\
\text { Chorioretinal coloboma } \\
\text { Microphthalmia and anophthalmia } \\
\text { Cataract } \\
\text { Nystagmus } \\
\text { Strabismus }\end{array}$ & $\begin{array}{c}50 \\
60 \\
10-45 \\
10 \\
30 \\
20\end{array}$ \\
\hline
\end{tabular}

The diagnosis includes three or more major criteria of ectodermal manifestations and at least one criterion of limb malformation.

\section{Discussion}

This case illustrates the clinical presentation of a newborn patient with Goltz syndrome (focal dermal hypoplasia). Manifestations vary among affected individuals, and many have only a subset of the characteristic features ${ }^{6}$. The lesions, as in this case, are presented since birth, and their expression is variable. Prognosis and treatment depend on the organs involved. Most individuals with focal dermal hypoplasia tend to have short stature since birth. The development is normal, although $15 \%$ of the cases reported present cognitive deterioration, but only in those that imply greater severity ${ }^{1,7}$.

Structural abnormalities of the brain and spina bifida have rarely been reported; seizures have also been described ${ }^{8}$.

The most characteristic skin lesions among patients with this syndrome are linear or reticular and follow Blaschko's lines, with cribriform atrophy, reddish or yellowish-red, hyperpigmentation and hypopigmentation in atrophic sites, and telangiectasia. The most frequently involved areas are the trunk and extremities, but any area of the tegument can be affected. Other skin findings include lipomatous nodules in atrophic regions and multiple raspberry-like papillomas at skin-mucosal and junction sites (including the mouth, nose, larynx, esophagus, and vaginal or rectal mucosa), which are not present at birth, but appear in the first months of life and increase progressively ${ }^{1}$. Other cutaneous alterations are patchy alopecia of the scalp, photosensitivity, sweating abnormalities, dermatoglyphic changes, and adnexal tumors ${ }^{1}$.

Regarding systemic malformations, the skeletal ones, which occur in $60-80 \%$ of cases, consist on syndactyly, ectrodactyly, oligodactyly, transverse defects of the limb (hand, elbow, forearm, and elbow without remaining distal portions including hemimelia and acheiria), hypoplasia or shortening of long bones, and costovertebral abnormalities such as fusion of ribs, hemivertebra, and butterfly vertebra, which are present since birth ${ }^{1,4}$. Within the ocular manifestations are colobomas, microphthalmia, anophthalmia, cataract, nystagmus, strabismus, and lacrimal duct abnormalities, among others occurring in $20 \%$ of the patients ${ }^{1}$. Dental malformations have been seen in more than half of the 


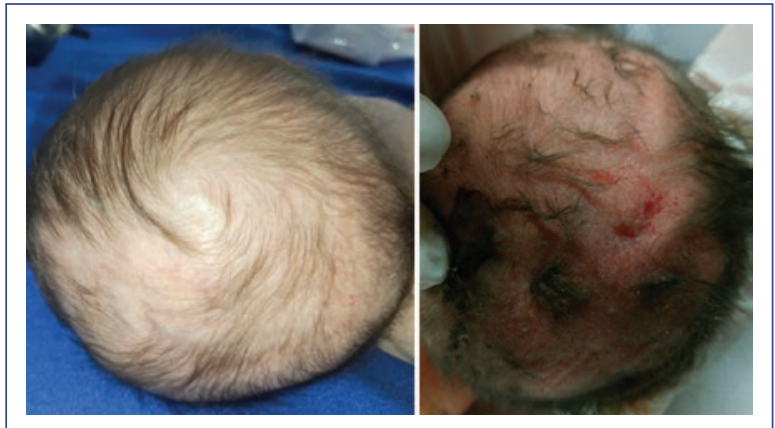

Figure 1. Areas of alopecia and hypoplasia of the dermis at 15 days old (left) and 1 month old (right).

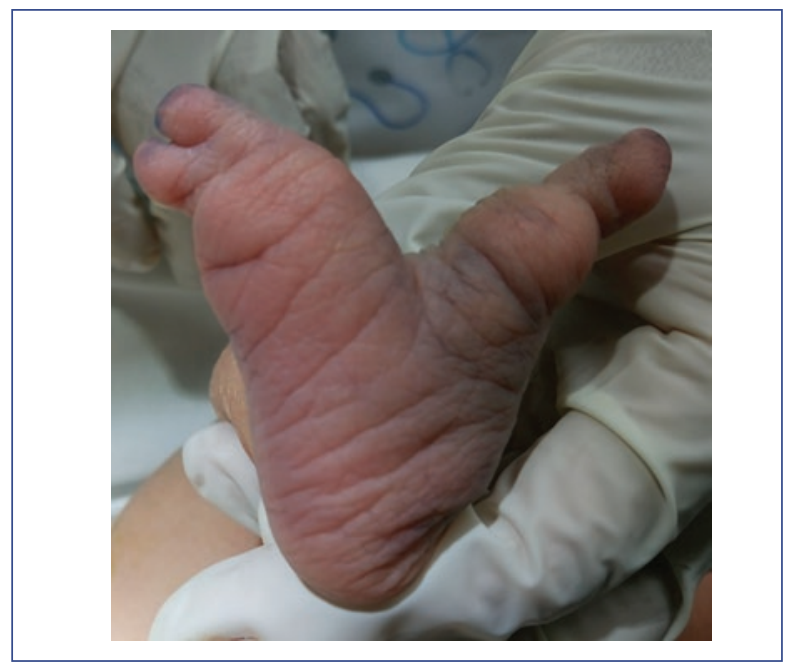

Figure 2. Ectrodactyly on the right foot.

cases and include hypodontia, oligodontia, supernumerary teeth, malocclusion, microdontia, taurodontia, fused teeth, and enamel dysplasia. Gastrointestinal manifestations have been reported such as poor weight gain, short stature, gastroesophageal reflux, gastroparesis, constipation, and food allergies. Renal agenesis, renal hypoplasia, horseshoe kidney, renal cystic dysplasia, and bicornuate uterus have been reported as renal and urogenital manifestations ${ }^{1,4}$. Cardiovascular manifestations include cardiac tumors, anomalous pulmonary venous connection, dextrocardia, and malformations such as truncus arteriosus ${ }^{4}$.

The diagnosis is based on the clinical (Table 1) and histological findings. Furthermore, there is a molecular study of the PORCN gene by sequencing analysis, detecting small deletions or duplications, insertions, nonsense, and missense mutations ${ }^{1,5,7}$.

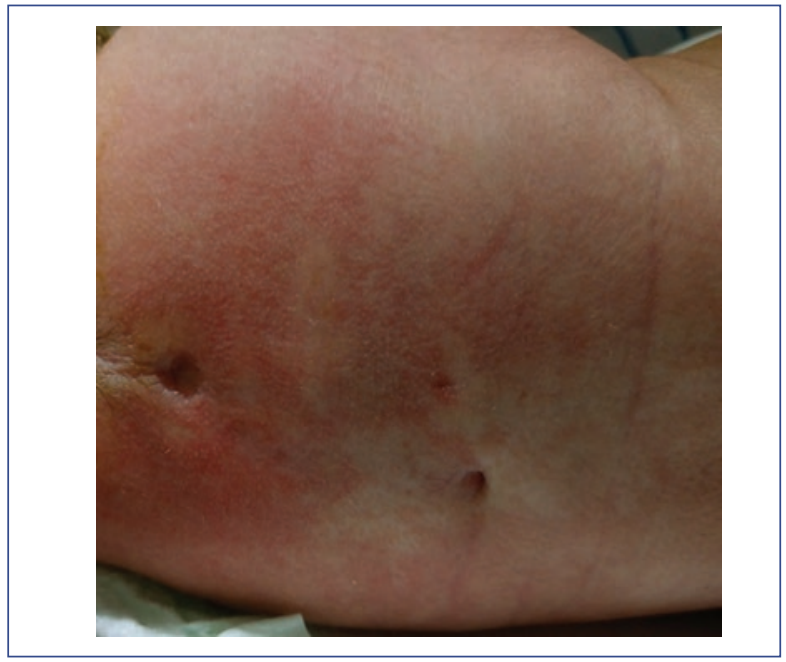

Figure 3. Herniation of lumbar fat.

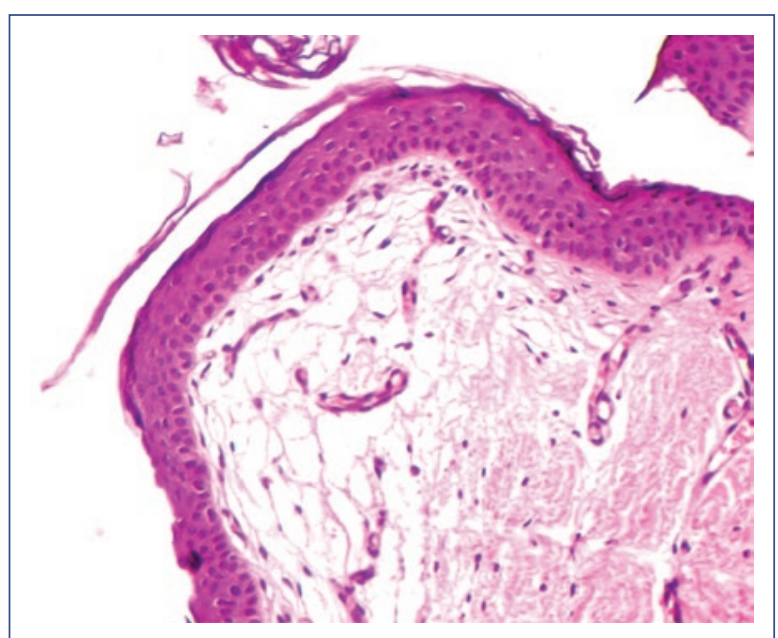

Figure 4. Skin biopsy with atrophy of the epidermis and dermal hypoplasia $(\times 40)$. The epidermis is continued almost directly with the subcutaneous cellular tissue.

The differential diagnosis includes Rothmund-Thomson disease (linear erythematous lesions indurated with photosensitivity, skin atrophy, and telangiectasia, although the dermis structure is normal $)^{9}$, incontinence pigmenti, nevus lipomatous, deletion on chromosome Xp22.2, Adams-Oliver syndrome, and aplasia cutis congenita ${ }^{10}$.

The diagnosis should be led by the Dermatology Department for skin lesions, treating pain in cases where it occurs, as well as erosive lesions and preventing secondary infections ${ }^{1,3,7}$. Skin lesions, especially facial ones, have an esthetic connotation, but there is no major 
therapeutic problem; the papillomatous lesions are generally surgically eliminated, but they are recurrent. Early plastic and orthopedic surgery improve limb deformities.

At the present day, about 300 cases of Goltz syndrome have been reported in the indexed global literature. To the best of our knowledge, the present case is the third one reported in Mexico.

\section{Ethical disclosures}

Protection of human and animal subjects. The authors declare that no experiments were performed on humans or animals for this study.

Confidentiality of data. The authors declare that they have followed the protocols of their work center on the publication of patient data.

Right to privacy and informed consent. The authors have obtained the informed consent of the patients and subjects referred to in the article. This document is in possession of the correspondence author.

\section{Conflicts of interest}

The authors declare no conflicts of interest.

\section{References}

1. Bostwick B, Van den Veyver IB, Sutton VR. Focal Dermal Hypoplasia. Gene Reviews $^{\circledR}$. Seattle: University of Washington, Seattle; 2008. Available at: http://www.ncbi.nlm.nih.gov/books/NBK1543

2. Bree AF, Grange DK, Hicks MJ, Goltz RW. Dermatologic findings of focal dermal hypoplasia (Goltz syndrome). Am J Med Genet C Semin Med Genet. 2016;172C:44-51.

3. Goltz RW, Peterson WC, Gorlin RJ, Ravis HG. Focal dermal hypoplasia. Arch Dermatol. 1962;86:708-17.

4. Morales ME, Ramos A, Gaxiola E, Barrera M. Hipoplasia dérmica focal (síndrome de Goltz). Rev Cent Dermatol Pascua. 2014;23:11-6.

5. Chico AB, Salene C, Juárez F, De los Ríos R, Saadi ME. Hipoplasia dérmica focal. Dermatol Argent. 2011;17:306-9.

6. Deustua S, Méndez T, Naranjo RM, Estévez Y, Escobar G. Síndrome de Goltz. Rev Cubana Oftalmol. 2016;29:735-40.

7. Acosta JC, Motta A, Prieto JC. Hipoplasia dérmica focal (síndrome de goltz): amplia variabilidad fenotípica. Rev Argent Dermatol. 2009;90:224-9.

8. Lawlor F, Holmes SC. Focal dermal hypoplasia syndrome in the neonate. J R Soc Med. 1989;82:165-6.

9. Temple IK, MacDowall P, Baraitser M, Artherton DJ. Focal dermal hypoplasia (Goltz syndrome). J Med Genet. 1990;27:180-7.

10. Pessoa V, Surana R. Focal termal hipoplasia. J Nat Med Assoc. 1979;71:829-31. 